\title{
Determination of antioxidant properties of Rumex crispus and Scrophularia canina subsp. bicolor
}

\author{
Serhat DEMİR*1, Buket BOZKURT ${ }^{1}$, Mustafa Ali ÖNÜR ${ }^{1}$, İrem Gülen KAYA ${ }^{1}$, \\ Nehir ÜNVER-SOMER ${ }^{1}$
}

${ }^{1}$ Department of Pharmacognosy, Faculty of Pharmacy, Ege University, 35100, İzmir-TURKEY

Received: 29 April 2017 - Accepted: 05 July 2017

\begin{abstract}
Methanol and ethyl acetate extracts of Rumex crispus L. and Scrophularia canina L. subsp. bicolor (SM.) Greuter were tested for their antioxidant activity using the DPPH method. Extracts were prepared from the above-ground parts of these plants. Significant antioxidant activity was determined for methanol $\left(\mathrm{IC}_{50}: 4.16\right.$ $\mu \mathrm{g} / \mathrm{mL}$ ) and ethyl acetate ( $\mathrm{IC}_{50}: 8.71 \mu \mathrm{g} / \mathrm{mL}$ ) extracts of Rumex crispus. Moreover, methanol ( $\left.\mathrm{IC}_{50}: 60.78 \mu \mathrm{g} / \mathrm{mL}\right)$ and ethyl acetate $\left(\mathrm{IC}_{50}: 149.33 \mu \mathrm{g} / \mathrm{mL}\right.$ ) extracts of Scrophularia canina subsp. bicolor (SM.) Greuter were shown to have important free radical scavenging antioxidant activity.
\end{abstract}

Keywords: Antioxidant activity, Rumex crispus, Scrophularia canina subsp. bicolor

\section{INTRODUCTION}

The genus Rumex L. (Polygonaceae) consists of about 200 species growing worldwide and 23 species and 5 hybrids naturally growing in Turkey. Rumex crispus L. is a perennial plant, and its basal leaves are acute and narrowly lanceolate to oblanceolate $[1,2]$. Various parts of Rumex species, including roots and fresh leaves, have been used in traditional medicine in Turkey. Rumex roots have important uses because of their laxative property. Decoctions prepared from the underground parts have been claimed to be therapeutically useful as cholagogue, tonic and laxative and for blood cleansing. Fresh leaves are used to treat eczema and also consumed as vegetable in Anatolia [3].

The name of Scrophularia comes from "scrofula", a kind of tuberculosis, since some species have been used for treatment of tuberculosis [4]. In the flora of Turkey, Scrophularia is represented by 59 species, 23 of which are endemic. Some Scrophularia L. species, especially $S$. nodosa L. are used in folk medicine as a diuretic and for the treatment of wounds and hemorrhoids [5, 6]. Different species of the genus Scrophularia (Scrophulariaceae) have been used in traditional medicine to treat some diseases, including dermatosis and inflammatory affections [7]. Besides that, some of Scrophularia species has shown anticancer and cell growth enhancing activities [8].

\footnotetext{
*Corresponding Author E-mail: eczserhatdemir@gmail.com
} 
Contrary to Scrophularia canina L. subsp. bicolor (SM.) Greuter there have been reports on the antioxidant activity of Rumex crispus species. The leaves, seeds and fruits of Rumex crispus have been shown to have antioxidant activity [9-10]. In the present study it is aimed to investigate the DPPH radical scavenging activity of methanol and ethyl acetate extracts prepared from Rumex crispus and Scrophularia canina subsp. bicolor.

\section{MATERIAL and METHODS}

\subsection{Plant Material}

Rumex crispus and Scrophularia canina subsp. bicolor were collected from Soma, Manisa. These plants were identified by Volkan Eroğlu and Hasan Yıldırım, respectively (Ege University, Faculty of Science). Voucher specimens are deposited in the Herbarium of the Department of Pharmacognosy, Faculty of Pharmacy, Ege University.

Above-ground parts of Rumex crispus and Scrophularia canina subsp. bicolor were powdered and $5 \mathrm{~g}$ powder of both plants were extracted with methanol and ethyl acetate (30 $\mathrm{ml}$ ) three times. Extraction was followed by filtration and the filtrate was evaporated to dryness by a rotary evaporator.

\subsection{Free Radical Scavenging Activity by DPPH Method}

Radical scavenging activity of the extracts were determined using DPPH (2,2-diphenyl1-picrylhydrazyl) method [11] with slight modification. Methanol and ethyl acetate extracts of Rumex crispus were tested within the range of $1.25-20 \mu \mathrm{g} / \mathrm{mL}$ concentrations. DPPH radical scavenging activity of methanol extract of Scrophularia canina subsp. bicolor was performed within the range of $25-400 \mu \mathrm{g} / \mathrm{mL}$ concentrations. Antioxidant activity of ethyl acetate extract of Scrophularia canina subsp. bicolor was determined by using a concentration range of 50$800 \mu \mathrm{g} / \mathrm{mL}$. DPPH solution was added to the extracts and the absorbance of the reaction mixture was measured at $517 \mathrm{~nm}$ after 30 minutes. Inhibition of free radical DPPH in percent (I \%) was calculated and a sample concentration providing $50 \%$ inhibition $\left(\mathrm{IC}_{50}\right)$ was calculated by plotting inhibition percentages against different concentrations of samples. The experiments were carried out in triplicate.

\section{RESULTS}

In DPPH assay, significant antioxidant activity was determined for methanol ( IC $_{50}: 4.16$ $\mu \mathrm{g} / \mathrm{mL})$ and ethyl acetate $\left(\mathrm{IC}_{50}: 8.71 \mu \mathrm{g} / \mathrm{mL}\right)$ extracts of Rumex crispus. The $\mathrm{IC}_{50}$ values of Scrophularia canina subsp. bicolor (methanol $\mathrm{IC}_{50}: 60.78 \mu \mathrm{g} / \mathrm{mL}$ ) and (ethyl acetate $\mathrm{IC}_{50}$ : $149.33 \mu \mathrm{g} / \mathrm{mL}$ ) extracts were higher than the extracts of former species pointing to a weaker antioxidant activity.

\section{DISCUSSION}

Rumex crispus and some Scrophularia species contain phenolic compounds [4-12]. Phenolic compounds are among the major secondary metabolites in plants responsible for their antioxidant activity (12). Therefore, antioxidant activity of these plant species may be due to their phenolic composition.

In conclusion, all of the extracts prepared from Rumex crispus and Scrophularia canina subsp. bicolor have been found to possess antioxidant activity. Future studies, regarding the determination of the components responsible for the free radical scavenging activity may be carried out to clarify the antioxidant potentials of these plants. 


\section{Conflict of Interests}

Authors declare that there is no conflict of interests.

\section{REFERENCES}

[1] Cullen, J. (1967). Rumex L.'" in Davis P.H. (ED). Flora of Turkey and East Aegean Islands, Edinburgh: University Press, 2, 281-293.

[2] Baytop, T. (1963). Medicinal and Poisonous Plants of Turkey, Akgün Press, University of Istanbul.

[3] Baytop, T. (1999). Therapy with Medicinal Plants in Turkey (Past and Present), Nobel T1p Kitabevleri.

[4] Mahboubi, M., Kazempour N., Nazar A.R.B. (2013). Total phenolic, total flavonoids, antioxidant and antimicrobial activity of Scrophularia striata Boiss. extracts, Jundishapur Journal of Natural Pharmaceutical Products, 8 (1), 15-19.

[5] Lall, S.S., Mill, R.R. (1978). Scrophularia L. In Davis P.H. (ED). Flora of Turkey and the East Aegean Islands. Edinburgh University Press, 6, 603-647.

[6] Çalış, I., Sezgin, Y., Dönmez A.A., Rüedi, P., Tasdemir, D. (2007). Crypthophilic Acids A, B, and C: Resin Glycosides from Aerial Parts of Scrophularia crypthophila, Journal of Natural Products, 70 (1), 43-47.

[7] Fernandez, M.A., Garcia, M.D., Saenz, M.T. (1996). Antibacterial activity of the phenolic acids fractions of Scrophularia frutescens and Scrophularia sambucifolia, Journal of Ethnopharmacology, 53, 11-14.

[8] Ardeshiry, Lajimia, A., Rezaie-Tavirani, M, Mortazavi, S., Barzegar, M., Moghadamnia, S., Rezaee, M. (2010). Study of anticancer property of Scrophularia striata extract on the human asrtrocytoma cell line (1321), Iranian J Pharma Res, 9 (4), 403-10.

[9] Maksimovic, Z., Kovacevic, N., Lakusic, B., Cebovic, T. (2011). Antioxidant activity of Yellow Dock (Rumex crispus L., Polygonaceae) fruit extract, Phytotherapy Research, 25, 101-105.

[10] Yıldırım, A., Mavi, A., Kara, A.A. (2001). Determination of antioxidant and antimicrobial activities of Rumex crispus L. extracts, J. Agric. Food Chem, 49, 40834089.

[11] Brand-Williams, W., Cuvelier, M.E., Berset, C. (1995). Use of Free Radical Method to Evaluate Antioxidant Activity, Lebensmittel-Wissenschaft \& Technologie, 28, 25-30.

[12] Coruh, I., Gormez, A., Ercisli, S., Sengul, M. (2008). Total phenolic content, antioxidant and antibacterial activity of Rumex crispus grown wild in Turkey, Pharmaceutical Biology, 46, 634-638. 